\title{
Measuring the Subjective Well-being of Teachers
}

\author{
Rosa Isela Gluyas Fitch \\ Alberto Baillères Foundation \\ Mexico \\ rosa.gluyas.fitch@gmail.com \\ María del Carmen Romero Sánchez \\ Centro Nacional de Evaluación para la Educación \\ Superior \\ Mexico \\ maricarmen.romero.s@gmail.com
}

\author{
Yutzil Tania Cadena Pedraza \\ UNAM \\ Mexico \\ yutzil.cadena@sociales.unam.mx
}

\author{
Monica Georgina Cinco Basurto \\ Institución Fundación EDUCA México, A.C. \\ Mexico \\ monica5@educa.org.mx
}

\begin{abstract}
This paper presents an instrument, designed using scientific methods, to measure the subjective well-being of teachers in relation to their work and to variables from life experience. Participant teachers work at the basic educational level in private institutions created by the civil society that attend to the needs of the socio-economically vulnerable populations outside the state's system. The Cronbach Alfa index and exploratory factor analysis were used to establish the reliability and validity of the instrument applied to 183 Mexican teachers in the pilot test. Conclusions pint out to possible uses of this validated instrument for the design of strategies that favor the integral well-being of the future generations of teachers and a substantial improvement in the quality of education.
\end{abstract}

Keywords: subjective well-being, instrument, teacher, health, and satisfaction.

Recieved 7 Nov 2017/Accepted 23 December 2017 @ JEHCP All rights reserved

\section{Introduction}

Studies carried out on teacher practice have been developed from various avenues within their work and personal dimensions. Martinez (200I) identifies three spheres from which teachers are studied: school, the work process, and the personal dimension, as far as health and subjectivity. Each sphere is considered of great relevance in making up the educational system. This study 
focuses on teacher health and subjectivity, to address the well-being of teachers and its effect on the quality of education.

The relationship between health, well-being, health problems and teaching practice was studied somewhat late in Latin America, with few studies published toward the end of the 80's and early 90's. Argentina and Chile were the first, with Ecuador, Mexico, Peru and Uruguay joining later (Parra, 2005). Because of these studies, toward the end of the $20^{\text {th }}$ century, several illnesses were identified in teachers: stress, neurosis, anxiety, burnout, dysphonia, myopia, absentmindedness, varicose veins, respiratory infections, depression, insomnia, gastritis, gynecological disorders, hypertension, and diabetes. The majority of these ailments can be attributed to working conditions and the lifestyle that the work schedules demand. Several other factors add to these physical and mental health ailments of the teachers, such as the teacher's low level of autonomy and the low satisfaction with the work process. On the other hand, and almost simultaneously, some aspects were found to contribute to the well-being of teachers, such as creativity or the teacher autonomy, as far as decision making (UNESCO, 2005; Garcia and Muñoz, 20 I 3; Cornejo, 2008).To these, others were added: self-realization, rooted beliefs, teachers' capability to face problems. Additionally, seven competencies to guarantee the well-being of teachers have been proposed: self-knowledge, self-esteem, emotional control, motivation, knowledge of others, valuing and leadership (Rodriguez, 2006; Hue, 20I2).

In this regard Esteve (1985), focusing on teacher ill-being, makes reference to the component of uncertainty: the teacher knows that something is not right, but is unable to identify the problem; unlike a disease, which is preceded by a diagnosis and involves an identification of it and of its origin (headache, body pain, etc.).In this way, the author suggests that many times, teachers' health problems are based on "an idyllic vision of the teaching profession that does not prepare future teachers to face real difficulties that will be found in the everyday working conditions" (Esteve, 2005: II8). He also suggests that the construction of teacher well-being begins with teacher training, to avoid difficulties in defining their professional identity, the definition of the objectives of the teaching role, the recognition of their teaching profile, and to master interaction, 
communication, and organizational skills in the classroom. Thus, teacher health problems are linked more to personal imbalance situations that affect the health of the teacher over time, affecting mostly the realm of mental health (stress, anxiety, neurosis, depression).

In the studies carried out on teacher health, well-being and health problems, the importance of objective, material, external conditions, such as the workplace infrastructure, salary, and benefits, has been demonstrated. However, there is evidence that teacher well-being is more closely related to subjective processes, fundamentally perception and affectivity, that result in either positive or negative performance according to the presenting context.

In recent years, there has been scientific work highlighting the influence of subjective processes of teachers (De Pablos, Colás y González, 20II).These studies have motivated a conceptual analysis on well-being, considering the variables that influence the satisfaction of human needs and that, according to García Martín (2002), are grouped into the following categories: health and socio-demographic variables, individual characteristics, behavioral variables and life events. The concept of happiness has also been incorporated and considered as the element that constitutes the meaning of life; it has been transposed into the teaching field under the premise that its promotion justifies individual and collective human actions.

Despite the late introduction of the concepts of subjective well-being and happiness to the models of teacher training and development, the interest in raising the quality of education, under the assumption that the teacher is a key element to achieve it, has contributed to consider the relevance of subjective well-being and the importance of its evaluation in educational contexts to identify the "standard of living" or "quality of life" that allow or inhibit the teacher in his formative work.

Researchers such as Fuentes and Rojas (200I) and Rogers and DeBoer (200I) have argued that the concept of life had as reference frame the Welfare State and its policies, making room for the term "quality of life". From the second half of the twentieth century, this term has been the 
subject of various studies through the correlation of economic variables and the subjective well-being variables.

Among the results of these studies, some stand outs are the creation of the Social Indicators Research (1974), a journal specialized in the study of quality of life and personal well-being, as well as other initiatives based on the application of periodic quality of life surveys; a few examples include the Survey of standard of living in Sweden (1968), the European Social Survey (2007) and the National Survey on Use of Time and Subjective Wellbeing in Mexico (20I4), among others. However, these studies have a quantitative approach and are linked to macrosocial socioeconomic indicators with an analysis perspective that originates from the political distribution of resources, recognized as the social engineering of Veenhoven (1994).

In addition to the quantitative approach, researchers such as Casas (1991), link the concepts of quality of life and well-being with subjective psychosocial measures of reality, based on perceptions and social evaluations related to the living conditions of people who integrate tending variables to subjectivity in terms of its measurement.

In this sense, studies such as the one we present in this article, on how well-being is reflected in the person-teacher-situation-training process interaction, and how the teacher's personal cognitions and characteristics intervene in the events of his life and in his work performance, allows having a greater understanding of the effect of being in the educational task and therefore of the results that teachers can obtain in the classroom.

Following these lines, this study presents the design and validation of an instrument to contribute to the understanding and measurement of subjective teacher well-being, linked to the workplace and to general life experience variables, in the context of Mexican educational institutions created by the organized civil society to attend to vulnerable urban areas that are not covered by the currently insufficient public-school system. 
Therefore, the instrument proposed in this research becomes the starting point so that in the first instance educational institutions can make a diagnosis about teachers' subjective well-being, and based on the results, design training programs that affect their level of well-being and satisfaction.

\section{Subjective Well-Being}

The concept of subjective well-being, used in psychology and to a lesser degree in sociology, refers to "the point of view" of the subject regarding his/her experience of life in general, as far as action, and links to property, to social environments and to other people. In other words, it evaluates the balance between cognition and the affection. This adds to a subjective evaluation of the satisfaction felt regarding various areas of life along with the affective balance that people conduct on emotions, emotional states, and feelings that have been experienced.

Satisfaction has been linked to the study of quality of life. Veenhoven (1994) holds that satisfaction with life refers to a value and positive judgment on something, especially to enjoyment that shows a global evaluation of life as a whole, not on a momentary state or referring only to an area of life. In this sense, it is defined as a mental state, a cognitive (significant) affective positive valuing on something, related to happiness, the generation of well-being and mental health.

In neuroscience, the influence of culture on well-being has been observed. Yamamoto (20|4) explains the correlation between biomarkers (such as oxytocin, cortisol, and vasopressin) in the process of obtaining happiness and satisfaction with life. He explains that in the problem-solution-happiness process, well-being does not refer to the lack of problems (including illness), but as the possibility of being able to solve problems in a controlled fashion. In this way, satisfaction refers to the perception of accomplishing goals that people set for themselves, defining satisfaction as either the accomplishment or frustration in meeting one's goals (Yamamoto \& Feijoo, 2007).

Addressing satisfaction as well, Herzberg's (1966) theory of two factors explains satisfaction and dissatisfaction as two separate processes, not as opposites. Herzberg proposes that there are two 
factors that organize the behavior of individuals:I) hygiene factors or those that prevent dissatisfaction, among which are the nature of interpersonal relationships, work environment conditions, and salary; and, 2) motivation factors as generating satisfaction in people, such as accomplishing an activity, recognition, the work itself, the acquired responsibility and the possibilities of promotion.

Herzberg poses that work-related satisfaction and dissatisfaction processes are understood differently, although not separately from the person's experience. He holds that when hygiene factors at work are unpleasant to the human experience, they generate dissatisfaction in the worker. However, when the experiences are pleasant, they do not increase satisfaction, they simply prevent the generation of dissatisfaction. In another scenario, when people do not experience satisfaction, that is, motivation factors are not pleasant, then people often seek stimuli in improving the hygiene factors (work environment, salary, etc.) although, the author points out, their effect in preventing dissatisfaction is of short duration.

From another perspective, emotions, feelings, affection and emotional states are part of the affective and symbolic sphere that joins biological, individual, and social processes (Calderon, 20I2), that is, the subjective processes. From this, we can infer the importance of integrating this affective dimension for the understanding of subjective processes and for producing well-being in whatever context developed in the human being.

The analysis of the previous approaches allows us to determine that perception is located as an inherent process in the production of satisfaction and affectivity, constituted by physiological and cultural elements, that is, processes of signification (Classen, 2009). In this sense, it has been found that for some cultures, family happiness is the principal source of pleasure and, therefore, of well-being (Yamamoto, 20I4). In this respect we have the reflection and the interest to answer in what way we can use these findings to strengthen the teacher well-being as a key variable in his/her role as trainer to achieve a favorable climate in the learning environment with positive 
results in the educational quality and in the formation of people who feel pleasure and well-being within the educational institutions.

\section{Teachers' Well-Being and Subjectivity}

Economically and culturally, work is considered as a necessary practice for the reproduction of life. Various senses and meanings are ascribed to it. Empirically during the course of life, work can mean being a means (temporary) or the aim (mission) of life (Cadena, 20I5).In both cases, emotions and emotional states that are generated, of either accomplishing a goal or not, should be understood as physiological and cultural processes because what might be considered agreeable in one culture might not seem so in another (Calderon, 20I2).

From a pedagogic standpoint, Esteve (2005) refers to the work of teaching as an ambivalent profession because, on the one hand, he recognizes that this activity is lived with optimism and becomes a source of professional self-realization since through this activity meaning can be found throughout an entire life. However, on the other hand, it is also recognized to be a demanding and exhausting process, always subject to the judgment by students. These references to the work of teaching, according to the author, are deemed, respectively, as teaching well-being and ill-being. Both aspects, apparently contradictory, are the two visible sides in the teachers of the Mexican educational system.

The perspectives derived from sociology and studies on work propose that the process of teaching is the transmission of meanings that is accomplished through social and symbolic interactions, which in turn, are based on physical and cognitive processes (De la Garza, 20I2).In this process, the stages of production, circulation, and consumption are carried out in the same act of teaching, since the knowledge that the teacher is to transmit first goes through internal processes of appropriation, assimilation, and interpretation in the teacher. This enables the teacher to facilitate the transference of the information and knowledge to the student, who, in turn, will take it in, assimilate and learn it, all through a non-material and subjective process. 
This is the way that teaching transcends from the transmission of information to the social, cultural and specific construction of the school (Martinez, 200I). In this, the subjective processes constitute a fundamental element for improving the learning processes and also generating teacher well-being in the personal and educational contexts. Therefore, subjective well-being, made up of its cognitive components that reveal satisfaction with life and the affections in the context of emotions and states of mind, becomes a key element that allows us to know how teachers evaluate, cognitively and affectively, their life in general and specifically, the educational context.

\section{Measurement of Subjective Teacher Well-Being}

The Organization for Economic Cooperation and Development (OECD) included the measurement of subjective well-being into its studies on progress and social development on an international level (OCDE, 2013).It proposed that quality of life cannot be determined or measured only by material or economic well-being, but that well-being should also be analyzed regarding the relationships people establish, affective and cognitively, on these materials or tangibles, as subjective aspects of life itself (Garcia, 2002; Castellanos, 2012; Rojas, 2009; 20II; Rojas and Martinez, 2012).The study of subjective well-being has also been considered as an indicator in the measurement of social accomplishment, as there is evidence that happy and satisfied people work better, increase their productivity, their creativity, and in case of illness, they recuperate faster (Millan, 20I4).

In Mexico, since 2012, the National Institute of Statistics and Geography (INEGI), the Consulting, Scientific and Technological Forum (FCC\&T) in collaboration with academia, have proposed a national, state-based measurement to collect statistical data that can be incorporated into the study, analysis and creation of public policy according to the needs of the society. The National Autonomous University of Mexico (UNAM) has also taken up in 2013 the Seminar on Subjective Satisfaction with Life and Society (SAVISO), from which the National Survey of Satisfaction with Life and Society (ENSAVISO) resulted. 
In the scientific world, three approaches have been identified on subjective well-being: the environmentalist, the psychological and the interactionist. In the first approach, the proposal of subjective well-being depends on external conditions and are linked to the environment. From this standpoint, teacher well-being would depend on the culture or the environment of the educational context. The second approach proposes that subjective well-being is linked to the personal characteristics of the subjects. From this standpoint, personal autonomy and control over surroundings are explored. The third approach, in which our study is positioned, proposes subjective well-beings a result of the relationship of contextual factors and personal ones (De Pablos, Colás and González, 20II).

Some of the fields or dimensions of life that Rojas and Martinez (20I2) suggest including in the measurement of subjective well-being and that give rise to the instrument designed in this study are: health, economy, work, family, friendships, free time, community, habitability, education, upbringing, religiousness and spirituality. In our measurement proposal of subjective well-being, we considered of prime importance not to leave out variables that interrelate the work and personal spheres: extra working hours that are added to the hours of paid work in the workplace and transportation time between work and home, which are conditions that cause the work of teachers to invade family space because work is taken home, and results in decrease of time for rest, recreation and mainly, for strengthening the family ties. Also included were socio demographic data, the description of disagreeable events or situations that were significant in the life experience of teachers, elements that although not belonging to the measurement of subjective well-being, were considered as key to consolidating an integral evaluation of the teachers.

In summary, this study proposes the addition of teachers' experiences and the variables implicit in them to the elements of satisfaction and emotional balance considered as conceptual axes that define subjective well-being, as bases for the design of the instrument proposed for the measurement of subjective well-being in teachers of the educational institutions of the EDUCA 
Network, created by the Mexican civil society as an answer to the lack of quality coverage that has not been able to be provided by the government.

\section{METHOD}

Objectives and Hypothesis

This study proposes to demonstrate the construct reliability and validity of an evaluation instrument designed to measure subjective well-being in teachers.

The hypotheses that underpin this study are:

a) That the proposed evaluation instrument has a reliable statistical coherence for the required task.

b) That the factor analysis confirms the existence of factors that explain teachers' subjective well-being.

\section{Elaboration of the Instrument for Evaluating Teachers' Subjective Well-Being}

The design process of an instrument to evaluate the subjective well-being of teachers takes principles put forth in several documents, mainly in the following: Measurement, Investigation and Incorporation into Public Policy of Subjective Well-being: Latin America, of the Consulting, Scientific and Technologic Forum (Rojas and Martinez, 20I2); the Expanded BIARE Questionnaire created by the National Institute of Geography and Statistics (INEGI, 20I4) and the ENSAVISO, 20I4, National Survey of Subjective Satisfaction with Life and Society developed by the National Autonomous University of Mexico (UNAM).

On the other hand, a review and analysis was made of the studies of the fields from which the teachers' situation for subjective well-being were taken (Martinez, 200I), especially those that reported on working conditions, health and teacher well-being in Mexico (UNESCO, 2005; Esteve, 2005; Parra, 2005; De Pablos, Colás y González, 20II; De la Garza, 2012). 
The instrument has three parts, with a total of 95 questions. The first part integrates the sub-dimensions or sub-scales to measure subjective teacher well-being. The second section incorporates a set of questions that will allow us to know the pleasant or unpleasant situations or events that the teachers lived during the previous 12 months. The last section includes social and work context data of the teachers.

The first scale, referring to teachers' subjective well-being, is divided into four dimensions, and developed in 45 questions.

I. Satisfaction with life in general and by areas of life: refers to the cognitive assessment /reflection that teachers carry out as to how they feel about their life in general and according to certain aspects of life, at the present moment. The areas of life proposed for exploration are friends, family, partner, health, achievements, free time, rest time, housing, neighborhood, city, country, and work (Rojas and Martinez, 2012; Diener, 2014).

2. Satisfaction with work and with work performance: This refers to the cognitive assessment/reflection that teachers carry out in relation to the work conditions they face. Some of them refer to the tasks and responsibilities in their charge, benefits, income, infrastructure of the educational center, work relations, promotion possibilities, autonomy and the time it takes to come and go from home to work (UNESCO, 2005). This dimension also includes aspects in reference to work performance, activities with students, parents, and co-workers, their professional background, the results of their teaching. These are aspects that have been studied regarding teacher performance (Valdes, 2009; SEP, 20I5).

3. Satisfaction with the economic situation in the last year: This dimension is based on the National Survey on Subjective Satisfaction with Life and with Society (2014) and refers to the cognitive assessment/reflection of the economic situation that the teacher receives and the ways that it allows covering or solving aspects of life such as material needs, illnesses, friendships, desires, affection, or problems.

4. Moods and emotions during the previous week: In some studies about teachers' health, mood and emotional alterations were related to emotional exhaustion, stress, depression, anxiety, insomnia, and difficulty concentrating (Parra, 2005; UNESCO, 2005, Rodríguez, 2006).It is 
because of this that this study takes up 10 emotional states (five positive and five negative) that the INEGI proposed in the Expanded BIARE questionnaire, which are good mood, tranquility, vitality, thoughtful, cheerful, bad mood, worry, fatigue, boredom and sadness (Expanded BIARE, 20I4).

The second section of the questionnaire is made up of 33 questions designed to find out about pleasant and unpleasant situations lived in the past 12 months, in the first or second person. These refer to economic solvency, illness, the death of a loved one, the birth of a healthy child, the purchase of a property, among others. This dimension adapts mainly from the Expanded BIARE survey of the INEGI because it allows contrasting the social context of the teacher with his/her subjective well-being.

The third section is made up of 18 questions geared to knowing personal data and aspects of the work conditions of the teachers. In this section, a set of data is explored that describe the social conditions of the teachers such as age, gender, civil status, education. Also, facts relating to the labor affiliation and working conditions, such as the name and location of the workplace, position, school level, number of students, benefits received, length of work experience, hours worked and salary are explored.

The design and application of this instrument allow for the collection of the most relevant aspects contributed by the scientific production regarding subjective well-being in Latin America, especially in Mexico. It is also proposed as an instrument in aiding to understand teacher subjective well-being in order to incorporate practices and strategies that promote their well-being with positive results in quality education and the school environment. The development of the proposed instrument may be consulted in Annex I.

In this section we present the validity and reliability analyses that were obtained through the SPSS software to calculate the Cronbach's Alpha coefficient of the general scale and the subscales, as well as the factorial analysis to check the validity of the construct. 


\section{Respondents}

After the instrument was developed, the validation of the battery of questions was carried out, as well as a pilot test on teachers of the EDUCA Network, of the EDUCA Mexico Foundation. In this pilot test, 183 questionnaires were answered by the teachers, mainly from Mexico City, and the States of Mexico, Queretaro, and Guanajuato; 82.2\% were women and 14.8\% were men. Primary school teachers were 42.8\%, 34.5\% were from initial and pre-school level, $15.5 \%$ were teachers in junior high school and 7.2\% taught in high school.

Regarding context, all of the participating schools were created by the organized civil society to address vulnerable context populations, that is, they are educational institutions that do not belong to the public sector but they are recognized and certified by the Ministry of Public Education. These schools are funded with donations, symbolic quotas and with the support of other civil society organizations regarding quality education, teacher training, and maintenance of the facilities.

\section{Analysis Data}

From the four sections of the instrument, we ran a statistical analysis of the sub dimensions or subscales that comprise the first section. We used the SPSS Statistics v23.0 computer program to analyze the psychometrics on the sub dimensions that allow the measurement of subjective well-being in order to determine the reliability and validity of the questions. Each of the subscales was measured individually and then as a whole.

The reliability (internal consistency) of the subscales was measured by calculating with Cronbach's Alpha, to ascertain the internal consistency among the various items, i.e., the degree of correlation among them; the minimum accepted value is of 0.650 and above .800 is considered a good result. The measurement of the subscales of the set that measures the subjective well-being of teachers was carried out first in general, and later, it was calculated for each of the subscales or sub dimensions. 
The questionnaire's coefficient of reliability was found to be .903 , a high level. Table I shows the results for each dimension or scale, in descending order:

Table I.

Reliability of the subscales (Cronbach's Alpha)

Subscale

\section{Cronbach's}

Alpha

Satisfaction of economic situation, in the last year (4 items)

State of mind and emotions, last week ( 10 items)

.895

.859

Job satisfaction and job performance (18 items)

.823

Satisfaction with life in general and by areas of life ( 13 items)

As shown in table I, all of the sub dimensions or subscales obtained acceptable and good values, which confirms that the questionnaire as a whole has a high-reliability level.

Internal validity was verified by an exploratory factor analysis of the main components. Previously, the Kaiser-Meyer-Olkin Sample Suitability Test was applied to the set of subscales with a result of .796. Bartlett's Test to prove pertinence of exploratory factor analysis gave a Chi-square of $3890.992, \mathrm{gl}=1035$ and $\mathrm{Sig}=.000$. These results indicated that the factor analysis was pertinent.

The exploratory factor analysis applied to all the subscales of the questionnaire showed I4 factors that explained $69.707 \%$ of the total of the variance and the statistical significance of the factors is $\mathrm{p}=.000$. These results indicate that the variance levels were high. The rotational factorial matrix applied showed the saturation of the variables of each factor. To guarantee the quality of the explained variables of each factor in this study, we opted for factorial saturations close to or above 
.40. In this way, the applied analysis reveals the existence of I I factors, as well as the variables that best saturate each factor.

The internal composition of these variables permits observation of the internal structure that explains the subjective teacher well-being related to life in general and to the work of teaching. All the variables are confirmed as describing relevant aspects to consider.

As with the previous analysis, the Kaiser-Meyer-Olkin test and the Bartlett test were applied to the data of the subscales. The results, shown in Table 2, confirm the pertinence of carrying out the factor analysis.

Table 2.

Results: subscales

\begin{tabular}{lcccc}
\hline \multirow{2}{*}{ Subscales } & Test & \multicolumn{3}{c}{ Bartlett Test } \\
\cline { 4 - 5 } & Káiser/Olkin & Chi-squared & gl & Sig \\
\hline Satisfaction with life in general and by areas & .699 & 560.185 & 78 & .000 \\
Satisfaction with work and job performance & .769 & 1079.723 & 153 & .000 \\
Satisfaction with economic situation in the past & .832 & 449.097 & 6 & .000 \\
year & .836 & 698.844 & 45 & .000 \\
\hline
\end{tabular}

Factor analysis by subscales

Satisfaction with life in general and by areas of life: The factor analysis showed three factors with values above I that explain $50.34 \%$ of the total of variance. The analysis of the variables that saturate each factor show the existence of three types of satisfaction related to life in general and by areas. The following table shows the designation that each factor suggests and the saturation value for each variable. 
Table 3

Results of the validity of the subscale construct "Satisfaction with life in general and with areas of life"

\begin{tabular}{cll}
\hline Item & Factor I: "Social satisfaction” & Saturation \\
& & Coefficient \\
\hline I & Currently, how satisfied are you with your life? & .77 I \\
3 & How satisfied am I with my relationship to my friends? & .64 I \\
4 & How satisfied am I with my relationship with my family? & .410 \\
6 & How satisfied am I with what I have accomplished in life? & .435 \\
9 & How satisfied am I with my housing arrangements? & .655 \\
I3 & How satisfied am I with my job? & .562 \\
\hline & Factor 2 "Physical-temporal satisfaction" & .432 \\
5 & How satisfied am I with my health? & .600 \\
7 & How satisfied am I with the free time I have to do what I want? & .854 \\
8 & How satisfied am I with the time I have to rest? & .89 I \\
\hline
\end{tabular}

Satisfaction with work and job performance: The factorial analysis showed five factors that explained $59.96 \%$ of the total of variance. As with the previous subscale, the significance level is .000 , which means there is a high level of confidence. The analysis of the factors suggests the existence of five types of satisfaction related to work and job performance. Table4 shows the denomination that each factor suggests and the saturation value for each of the variables. 


\section{Table 4}

Results of the validity of the subscale "Satisfaction with work and job performance"

\begin{tabular}{|c|c|c|}
\hline Item & Factor I: "Institutional satisfaction" & $\begin{array}{l}\text { Saturation } \\
\text { coefficient }\end{array}$ \\
\hline 15 & $\begin{array}{l}\text { How satisfied am I with the tasks and responsibilities that I have } \\
\text { in my work as a teacher? }\end{array}$ & .659 \\
\hline 16 & $\begin{array}{l}\text { How satisfied am I with the social and welfare benefits that I get } \\
\text { in my job? }\end{array}$ & .760 \\
\hline 17 & How satisfied am I with the income I receive from my job? & .714 \\
\hline 18 & How satisfied am I with the facilities of the school where I work? & .408 \\
\hline 20 & $\begin{array}{l}\text { How satisfied am I with the respect and social acknowledgment } \\
\text { that is given to me in my job? }\end{array}$ & .755 \\
\hline 21 & $\begin{array}{l}\text { How satisfied am I with the promotion possibilities to obtain a } \\
\text { better position in my job? }\end{array}$ & .674 \\
\hline 22 & $\begin{array}{l}\text { How satisfied am I with the opportunities to be creative, to } \\
\text { propose ideas and apply them to my work? }\end{array}$ & .690 \\
\hline 23 & $\begin{array}{l}\text { How satisfied am I with the hours of my job, with my work } \\
\text { schedule? }\end{array}$ & .432 \\
\hline 25 & $\begin{array}{l}\text { Factor } 2 \text { "Self-initiative Satisfaction" } \\
\text { How satisfied am I with how punctual I have been in arriving at } \\
\text { work? }\end{array}$ & .628 \\
\hline 26 & $\begin{array}{l}\text { How satisfied am I with my participation in activities organized } \\
\text { with the students? }\end{array}$ & .626 \\
\hline 29 & $\begin{array}{l}\text { How satisfied am I to with the possibility of continuing my } \\
\text { professional preparation through courses or workshops? }\end{array}$ & .639 \\
\hline \multirow[t]{2}{*}{30} & $\begin{array}{l}\text { How satisfied am I with the activities that I carry out to enable } \\
\text { my students' learning? }\end{array}$ & .723 \\
\hline & Factor 3 “Interpersonal satisfaction” & \\
\hline 19 & $\begin{array}{l}\text { How satisfied am I with the relationships with the friends I have } \\
\text { at work? }\end{array}$ & .756 \\
\hline 27 & $\begin{array}{l}\text { How satisfied am I with my participation in the activities } \\
\text { organized with the parents? }\end{array}$ & .551 \\
\hline \multirow[t]{2}{*}{28} & $\begin{array}{l}\text { How satisfied am I with my participation in work meetings with } \\
\text { my co-workers? }\end{array}$ & .778 \\
\hline & Factor 4 "Satisfaction by accomplishments" & \\
\hline 31 & How satisfied am I with my ability to handle a computer? & .788 \\
\hline 32 & $\begin{array}{l}\text { How satisfied am I with the goals I have reached, with respect to } \\
\text { the work program? }\end{array}$ & .701 \\
\hline & Factor 5 "Satisfaction with mobility" & \\
\hline 24 & $\begin{array}{l}\text { How satisfied am I with the time it takes for me to get from } \\
\text { home to work? }\end{array}$ & .739 \\
\hline
\end{tabular}

Satisfaction with the economic situation in the last year: The exploratory factor analysis identified one factor that explains $76.21 \%$ of the total of variance. As with the previous subscales, the statistical level of the coefficients that were found was significant. Table 5 shows that the factor weights of each variable were high, indicating the subscale internal consistency was good. 


\section{Table 5}

Results of the validity of the subscale "Satisfaction with economic situation in the last year"

\begin{tabular}{clc}
\hline Item & One factor & $\begin{array}{c}\text { Saturation } \\
\text { coefficient }\end{array}$ \\
\hline 33 & $\begin{array}{l}\text { How satisfied am I with my economic situation because it allows me } \\
\text { to cover my needs and those of my family? }\end{array}$ & .902 \\
34 & $\begin{array}{l}\text { How satisfied am I with my economic situation because it allows me } \\
\text { to live the way I want? }\end{array}$ & .887 \\
35 & $\begin{array}{l}\text { How satisfied am I with my economic situation because it allows me } \\
\text { to feel appreciated and respected socially? }\end{array}$ & .718 \\
36 & $\begin{array}{l}\text { How satisfied am I with my economic situation because it allows me } \\
\text { to face problems, such as illnesses or accidents? }\end{array}$ & .799 \\
\hline
\end{tabular}

States of mind and emotions, during the past week: The factor analysis showed two factors that explain $56.28 \%$ of the total of variance. The analysis of the variables that saturate each factor suggest the existence of two types of states of mind and emotions, shown in table 6 that indicates the denomination that each factor suggests and the saturation value for each variable.

Table 6

Results of the validity of the subscale "States of mind and emotions, during the past week"

\begin{tabular}{cll}
\hline Item & Factor I: "States of mind and emotions, positive" & Saturation coefficient \\
\hline 37 & I was in a good mood last week & .760 \\
38 & I was calm and tranquil last week & .799 \\
39 & I felt energy and vitality last week & .724 \\
40 & I was concentrated/focused in what I was doing last week & .412 \\
4 I & I felt happy last week & .719 \\
\hline & Factor 2: "States of mind and emotions, negative" \\
& & .645 \\
42 & Last week I was in a bad mood & .552 \\
43 & Last week I felt worried, anxious or stressed & .564 \\
44 & Last week I felt tired or lacking in vitality & .840 \\
45 & Last week I was bored or felt no interest in what I was doing & .82 I \\
46 & Last week I felt sad
\end{tabular}




\section{Results}

Given that the instrument proved to be valid and reliable, the evaluation of the subjective well-being of EDUCA NETWORK teachers is integrated by cognitive and affective elements that determine the level of satisfaction with 12 different aspects of their life: friends, family, partner, health, achievements, spare time, rest time, housing, neighborhood, the city, the country and work. For the analysis of results, the evaluation of satisfaction is translated into numerical values and on a scale from I to 5, where I represents "very dissatisfied" and 5 represents "very satisfied".

The results on subjective well-being include a level of satisfaction of life in general and the I 2 areas of life that make up the instrument. Teachers also report the affective exploration of their emotional condition from the previous week, before responding the instrument (during the months of June-July 2016). Afterward, the results of subjective well-being are presented in correlation with aspects of working life and the economic situation they experience.

Satisfaction with life in general and with areas of life

To the question: How satisfied am I with my life? The teachers, with an average value of 4.39 (on a scale of I to 5), evaluate their life in general with satisfaction. After, when observing the value assigned to each of the 12 areas of life, it was observed that the area with the greatest satisfaction is that of the family (with a value of 4.67), then the field of friends (with a value of 4.43), personal achievements (with a value of 4.40), work (with a value of 4.19), partner (with a value of 4.16), housing (with a value of 4.09) and health (with a value of 4.02). On the other hand, the areas with the lowest satisfaction reported are: the area of the neighborhood (with a value of 3.77), the area of spare time (with a value of 3.53), the rest time (with a value of 3.35 ) and the city (with a value of 3.2I). Finally, the following graph shows, the area that is evaluated as most unsatisfactory (with a value of 2.80 ) is the one that refers to the country.

The results help us to identify that the factors that interfere in the teachers' level of satisfaction are spare time and rest time. We also identified the critical components that affect the teacher: their neighborhood, city and country. 
Of these factors, the relationship of the teacher with the national (country), urban (city) and local

(neighborhood) dimensions, as well as the time of non-work (spare time and rest time) is relevant. This allows us to conclude that in terms of work, teachers are satisfied with their work but not with the time they have for rest or recreation.

To close this section, it is worth noting a difference regarding the satisfaction of teachers with "life in general" and its correlation with "the twelve areas of life". At the beginning of this section we presented the assessment that teachers give, at first, when answering the first question of the instrument "How satisfied am I with my life?" In this respect, the general assessment was 4.39. However, after presenting the teachers' evaluations to "the twelve areas of life", the average value of 3.8 was obtained. This shows a lower level of satisfaction compared to the value given in the initial valuation (value of 4.39 ).

This difference could be due to the depth of reflection to internalize the level of satisfaction from a general position in contrast to a specific discernment for each area of life.

\section{Satisfaction with work life}

The instrument explored the cognitive and affective evaluation on 18 aspects related to the teachers' working conditions and to the activities they carry out in their work. The values obtained from the statistical analysis are translated, on a scale from I to 5, where I represents "very dissatisfied" and 5 "very satisfied".

The following graph shows values are positive, however, some contrasts are revealed between the positive values obtained from aspects that relate more directly to the initiative and activity of the teacher as a person: the continuity of professional preparation (4.37), punctuality (4.37), the participation in activities with the students (4.36), work friendships (4.25), the activities that are carried out to facilitate the students' learning (4.23) the reached goals (4. I8), among others, to the values obtained in aspects related to the conditions of the teaching context such as income (3.22), benefits obtained through work (3.49), promotion possibilities (3.6I), respect and social recognition for their work (3.88), among others. 
Five types of aspects integrate work life: I) Those related or defined institutionally: The tasks and responsibilities of the teacher, the benefits you get for your service, income, school center, the respect and social recognition of the teaching work, the possibilities of promotion, the possibilities to be creative in the development of work and the work schedule; 2) Those that involve mainly teacher initiative: Punctuality, participation in activities that are organized to facilitate student learning and continuity in the professional preparation of the teacher; 3 ) Those aspects that refer to interpersonal relationships at work: Friendship relationships, teacher activities with parents and in work meetings with colleagues; 4) Those aspects that refer to achievements obtained in the improvement of their teaching work: Objectives or goals obtained and the ability to handle the computer; 5) Finally, we identified a fifth aspect that refers to the teacher's mobility to get to work, this refers specifically to the time aspect of the commute from home to work and vice versa.

From this classification, most of the aspects related or defined by the institution are those to which the teacher assigned the least value, among them are the work benefits and the salary that the teacher receives from their work. While the aspects related or derived from the teacher's initiative were evaluated in their entirety in a positive way, such as professional preparation, punctuality and teacher participation in activities with students.

\section{Satisfaction about the economic status}

Teachers' satisfaction with their economic status results' are the less satisfactory aspects in the whole survey. The evaluation that the teachers do respecting their economic situation can be observed in relation to four items: I) what they consider their needs and those of their family, 2) what they desire in life, 3) the social appreciation and respect acquired, and 4) the possibility of facing illnesses and accidents.

The results of the evaluation made by teachers about their economic situation reflects the minimum level of satisfaction, considering that the score that represents a "very satisfactory" evaluation is from 5 to a minimum of satisfaction represented with 3 points. When comparing the 
satisfaction levels that the teachers expressed for each item, we can determine that the teachers evaluate with a minimum level of satisfaction their economic situation in relation to the appreciation and social respect they receive (with a value of 3.52 ), the possibility of covering certain needs of the teachers and their families (with a value of 3.25). An almost zero satisfaction is shown on the economic situation when related to the satisfaction of the life desired by the teachers (with a value of 3.16 points) and we observe no satisfaction when the economic situation is related to the possibility to solve expenses due to illness or accident (with a value of 3 ).

Undoubtedly, the evaluation of teachers' economic situation agrees with the low satisfaction that teachers expressed about their income and the benefits they obtain for their work. This low satisfaction due to the economic situation reflects the limitations in economic terms to achieve the desired life and, above all, to solve expenses that are generated by health or unforeseen events in case of an accident.

\section{Affective balance}

Regarding the teachers' affective balance, we observed that from a set of ten emotional states (good mood, calm, concentration, happiness, energetic, bad mood, stress, tiredness, boredom and sadness) the evaluation assigned by the teachers reflects a positive affective balance; although, in general terms, the evaluation is at the possible minimum to be considered positive within the scale. For the analysis, the coding of the answers was established on a scale of I to 5 , where I represents the lowest frequency with which the emotional state was experienced and 5 represents the highest frequency with which the emotional state was experienced.

In this way, we observed that the emotional states that teachers experience, from higher to lower frequency, are: being concentrated (with the value 4.19), happiness (with a value of 4.II), being in a good mood (with 4.04), feeling energetic (with 3.76), feeling calm or at ease (with 3.5 I), feeling worry or stress (2.47), feeling tired (2.32), being in a bad mood (2.0I), feeling sad (I.56) and boredom (I.4I). 
As the graph shows, teachers can experience a variety of emotional states, even though they could be contradictory (for example good / bad mood). However, teachers report higher frequency with positive emotions and mood states. In general, teachers report a positive affective balance, in which the level of concentration, happiness and good mood are more frequently identified.

\section{DISCUSSION}

The question of whether "feeling good" influences work performance has been studied by many researchers such as Campbell (198I) and Diener (1984), who have tried to identify the causes and consequences of the emotional state of the person in positive functioning. In fact since Jung (1993), researchers have tried to visualize the person in a multidimensional way, and therefore have sought indicators of well-being in empirical research to try to impact their performance in different areas of their lives, such as the work life. However, the measurement of subjective well-being is limited in the teachers; it is a field that has not been fully explored. In this sense, the relevance of approaching this type of studies represents a wide range of possibilities, because the well-being of the person is linked to the performance of the teaching, which is fundamental for the education of the 2 Ist century, because whoever is in front of a group performing an educational work must be well with itself in order to be able to facilitate the teaching-learning process and maximize their ability to create environments that promote learning and provide wellbeing conditions for students in the educational context.

The results were obtained after the development and application of the instrument to 183 teachers verify its validity and reliability to measure the subjective well-being of the teacher in four groups of questions:

I. Satisfaction with life in general and with areas of life

II. Satisfaction with work and job performance

III. Satisfaction with economic situation in the last year

IV. States of mind and emotions, during the past week 
The process of validity and reliability shows that the proposed instrument does not oppose to an objective assessment, and complements the result with the reality that the subjects live, the reality that guides them and that acts as a reference to perform in the different areas of their life.

The cognitive element in the evaluation process is shown to be linked to the emotional and affective components, since the level of satisfaction is based on the acceptance and personal growth of the teachers, as well as on the adaptation of the conditions of their context and their integration in the social environment. In this sense, self-acceptance, autonomy and control over the personal and the work environments can be achieved through internal processes such as motivation, the change of perception of the self or the context to the extent of modifying the aspirations or conditions to favor the environment.

The measurement of well-being becomes a necessity to rescue the human part of the teacher, to identify which are the dimensions that limit or increase their well-being in order to maximize the conditions, as well as the elements that will allow their human development in the first instance, and as consequence, their optimal personal development with a positive impact on the education of the new generations.

To ignore teachers' well-being would be a negligence against the educational models of the 2 Ist century, in which the development of socio-emotional competencies with an integral vision of the human being becomes a fundamental part of the educational process. The student is at the center of the models, but the teachers are the ones who facilitate the process, therefore, their well-being is not an aspiration, it is a requirement to achieve educational quality.

\section{CONCLUSION}

The study presented here offers a key support to enrich the dimensions that make up teacher evaluation by presenting a validated and reliable instrument that evaluates subjective well-being with a humanist focus. As a limitation of the study, the instrument was implemented in a limited 
context; by this we mean that, although the instrument revealed acceptable preliminary psychometric properties, it was piloted with a sample of teachers that work at the basic educational level in private institutions created by the civil society that attend to the needs of the socio-economically vulnerable populations outside the state's system.

Within this context, it is fundamental to recognize that in a country like Mexico, with a marked diversity of contexts, it is necessary to pilot the instrument in different population typologies to make the appropriate adjustments, since in each of them there could be other dimensions to consider and other factors that influence the visualization of another conception of the teacher's well-being, such as: conditions, culture and ethnicity. Therefore, the results obtained with the proposed instrument represent an approximation to the measurement of subjective well-being in teachers, as a starting point for the consolidation of a more robust instrument that is applicable in other contexts with different types of population.

In this sense, the scope of the next phase of this study considers implementing the same evaluation process with teachers of public and private schools, in order to perform a comparative analysis to identify those variables that integrate subjective well-being and are applicable in various educational contexts, with the purpose of having an instrument that can be applied at the national level and be a reference at the international level.

The principle of this study is teachers are human beings that hold in their hands the transcendental task of forming other human beings and whose conditions and experiences in life in various contexts are fundamental variables to consider when grading their performance. The presentation of this instrument promotes the application of evaluation models to education with an integral vision centered on the person so that with this as a base, educational institutions can design and incorporate strategies that favor the integral well-being of the future generations of teachers and can project this toward a substantial improvement in the quality of education. 


\section{References}

Campbell, A. (198I). The sense of well-being in America. New York, USA: McGraw-Hill.

Casas, F. (|99|). El concepto de calidad de vida en la intervención social en el ámbito de la infancia [The concept of quality of life in social intervention in the field of childhood]. In Colegio Oficial de Psicólogos (Ed.), III Jornadas de Psicología de la Intervención Social (pp. 649-672). Madrid, Spain: Instituto Nacional de Servicios Sociales.

Castellanos, R. (20I2). El bienestar subjetivo como enfoque e instrumento de la política pública: una revisión analítica de la literatura [Subjective wellbeing as an approach and instrument of public policy: an analytical review of literature]. Revista Chilena de Administración Pública, 19, 133-168.

Cadena, Y. (20I5). Imaginarios laborales: Percibir, significar y representar el trabajo en la Ciudad de México [Work Imaginaries: Perceiveing, signifying and representing work in Mexico City] (Doctoral dissertation). Universidad Autónoma Metropolitana, Iztapalapa, México.

Calderón, E. (20I2). La afectividad en antropología: una estructura ausente [Affectivity in anthropology: an absent structure]. Iztapalapa. México: Centro de Investigaciones y Estudios Superiores en Antropología Social-UAM.

Classen, C. (2009). Fundamentos de una antropología de los sentidos [Fundamentals of an anthropology of the senses]. Paris, France: UNESCO.

Cornejo, R. (2008). Salud laboral docente y condiciones de trabajo [Teacher health and work conditions]. Profesión Docente, 35, 77-85.

De la Graza, E. (2012). El trabajo no clásico y la amplicación de los conceptos de la Sociología del Trabajo [The non-classical work and the amplification of the concepts of the Sociology of Work]. Revista del Trabajo, 10, 109-123.

De Pablos, J. M., Colás, P. S. \& González, M. T. (20II). Bienestar Docente e Innovación con Tecnologías de la información y la Comunicación [Teacher Well-being and Innovation with Information and Communication Technologies.]. Revista de Investigación Educativa, 29(I), $59-81$.

Diener, E. (1984). Subjective well-being. Psychological Bulletin, 95, 542-575.

Diener, E. (2000). Subjetive well-being: The science of happiness and a proposal for a national index. American psychologist, 55(I), 34-43.

Esteve, J. (2005). Bienestar y salud docente [Teacher well-being and health.]. Revista PRELAC, I,II7-I33. 
Fuentes, N. \& Rojas, M. (200I). Economic theory and subjective well-being: Mexico. Social Indicators Research, (53)3, 289-3I4.

Garcia, M. C. \& Muñoz, A. I. (20I3). Salud y trabajo de docentes de instituciones educativas distritales de la localidad uno de Bogotá [Health and work of teachers of district educational institutions of the Bogota's locality one]. Avances en Enfermería, 3 I (2), 30-42.

García, M. A. (2002). Bienestar Subjetivo [Subjective well-being]. Escritos de Psicología, I8, I8-39.

INEGI (20I4). Módulo de Bienestar Autorreportado [Self-reported Wellbeing Module]. México: INEGI. Retrieved from: http://www.inegi.org.mx/inegi/contenidos/investigacion/experimentales/bienestar/doc/biare _ampliado_cuest.pdf

Herzberg, F. (1966). Work of the Nature of man. Cleveland, USA: The World of Publishing Company.

Hué, C. (20I2). Bienestar docente y pensamiento emocional [Teaching well-being and emotional thinking]. Revista Fuentes, 12, 47-68 Retrieved from: http://institucional.us.es/revistas/fuente/I2/art_I.pdf

Jung, C. G. (1933). Modern man in search of a soul (W.S. Dell \& C.F. Baynes, Trans.). New York, USA: Harcourt, Brace, \& World.

Martínez, D. (200I). Abriendo el presente de una modernidad inconclusa: treinta años de estudios del trabajo docente [Opening the present of an unfinished modernity: thirty years of studies of teaching work]. XXIII International Congress, Latin American Studies Association (LASA), Washington DC, September 6-8.

Millán, R. (20l4). Lo subjetivo en el bienestar [Subjectivity in well-being]. Seminario Internacional Bienestar Subjetivo: Medición y uso en las políticas públicas y toma de decisiones en México y Latinoamérica. Retrieved from: https://www.youtube.com/watch?v=TjkB__rBOZU

OCDE (20I3). OCDE Guidelines on Measuring Subjetive Well-being. Paris: OECD. Retrieved from: http://dx.doi.org//0.1787/9789264191655-en

Parra, M. (2005). Condiciones de trabajo y salud en el trabajo docente [Teaching Work and Health Conditions]. Revista PRELAC, I, I35-I45.

Rodríguez, M. (2006). Salud emocional en profesores de secundaria y desequilibrio de esfuerzo-recompensa, una comparación entre escuelas de administración pública y privada (Informe final) [Emotional health in secondary school teachers and effort-reward imbalance, a comparison between public and private schools (Final report)]. Transformaciones en el mundo del trabajo: efectos socio-económicos y culturales en América Latina y el Caribe. Programa Regional de Becas CLACSO. Retrieved from: http://bibliotecavirtual.clacso.org.ar/ar/libros/becas/2005/2005/trabjov/rodriguez.pdf 
Rogers, S.J. \& DeBoer, D. (200I). Changes in wives' income: Effects on marital happiness, psychological well-being, and the risk of divorce. Journal of Marriage and Family. DOI: I0.IIII/j.I74I-3737.200I.00458.x

Rojas, M. (2009). Midiendo el progreso de las sociedades. Reflexiones desde México [Measuring the progress of societies. Reflections from Mexico]. México, DF: Foro Consultivo, Científico y Tecnológico.

Rojas, M. y Martinez, I. (20I2). Medición, Investigación e Incorporación a la Política Pública del Bienestar Subjetivo: América Latina [Measurement, Research and Incorporation to the Public Policy of Subjective Well-Being: Latin America]. México, DF: Foro Consultivo, Científico y Tecnólogico.

SEP (20I5). Perfil, parámetros e indicadores para docentes. Evaluación del Desempeño Docente Ciclo Escolar 2015-2016 [Profile, parameters and indicators for teachers. Teaching Performance Evaluation 2015-2016 School Cycle]. México: SEP.

UNAM-IIS (20I5). Encuesta Nacional sobre Satisfacción Subjetiva con la Vida y la Sociedad. Seminario Satisfacción Subjetiva con la Vida y la Sociedad (SAVISO) [National Survey on Subjective Satisfaction with Life and Society. Subjective Satisfaction with Life and Society Seminar (SAVISO)]. Retrieved from: http://www.pued.unam.mx/SUCS/2015/I803I5RMV.pdf

UNESCO (2005). Condiciones de trabajo y salud docente [Working conditions and teaching health]. Santiago, Chile: Oficina Regional de Educación de la UNESCO para América Latina y del Caribe.

Valdés, H. (2009). Manual de buenas prácticas de evaluación del desempeño profesional de los docentes [Manual of good practices for evaluating the professional performance of teachers]. Lima, Perú: Consejo Nacional de Educación.

Veenhoven, R. (1994). El estudio de la satisfacción con la vida [The study of satisfaction with life]. Intervención Psicosocial, 3, 87-II6.

Yamamoto, J. (20l4). Los fundamentos científicos de la Medición del Bienestar Subjetivo [The scientific foundations of the Measurement of Subjective Wellbeing]. Seminario Fundamentos científicos de la medición del Bienestar Subjetivo. INEGllnforma. Retrieved from: https://www.youtube.com/watch?v=yQhqzYjagqw

Yamamoto, J. \& Feijoo, A. R. (2007). Componentes émicos del bienestar. Hacia un modelo alternativo de desarrollo [Emic components of well-being. Towards an alternative development model]. Revista de Psicología, 25(2), I98-23I. 


\section{Annex I}

\section{QUESTIONNAIRE}

First Section: Measures the subjective wellbeing of teachers Indicate with an $\mathrm{X}$ the answer that is closes to your degree of satisfaction.

I=Very dissatisfied, 2=Dissatisfied, 3=Neither satisfied nor dissatisfied, 4=Satisfied and 5=Very satisfied.

I. Currently, how satisfied am I with my life?

2. How satisfied am I with the relationships with my friends?

3. How satisfied am I with my relationship with my family?

4. How satisfied am I with my relationship as a couple?

5. How satisfied am I with my health?

6. How satisfied am I with what I have accomplished in my life?

7. How satisfied am I with the free time I have to do what I like to do?

8. How satisfied am I with the time I have to rest?

9. How satisfied am I with my living quarters?

10. How satisfied with the area where I live?

I I. How satisfied am I with my city?

I2. How satisfied am I with my country?

13. How satisfied am I with my job?

14. How satisfied am I with my tasks and responsibilities that I have in my work as a teacher?

15. How satisfied am I with the social and welfare benefits that I obtain in my job?

16. How satisfied am I with the income I receive for my work?

I7. How satisfied am I with the facilities of the school where I work?

18. How satisfied am I with the friendship relationships I have at my job? 
19. How satisfied am I with the respect and recognition I am given at work?

20. How satisfied am I with the promotion possibilities or with being able to obtain a better positon at work?

2I. How satisfied am I with the opportunities to be creative, to propose ideas and to apply them to my work?

22. How satisfied am I with the hours of work?

23. How satisfied am I with the time it takes me to go from home to work?

24. How satisfied am I with how punctual I have been able to be to get to my job?

25. How satisfied am I in my participation in activities organized with the students?

26. How satisfied am I with my participation in the activities organized with parents?

27. How satisfied am I with my participation in work meetings with my co-workers?

28. How satisfied am I in continuing my professional preparation through courses or workshops.

29. How satisfied am I with the activities that I carry out to enable my students' learning?

30. How satisfied am I in my ability to handle a computer.

3I. How satisfied am I with the goals I have reached, with respect to the work program?

32. How satisfied am I in my economic situation because it allows me to cover my needs and the needs of my family?

33. How satisfied am I with my economic situation because it allows me to live the way I want?

34. How satisfied am I of my economic situation because it allows me 
to feel appreciated and respected socially?

35. How satisfied am I with my economic situation because it allows me to face problems such as illnesses or accidents?

Indicate with an $\mathrm{X}$ the answer that is closest to what you have lived (Choose only one). I=At no time during the week. 2=For a little while during the week. $3=$ Half the time during the week. 4=Most of the time during the week. 5=Every day of the week.

36. Last week I was in a good mood...

37. Last week I felt peaceful...

38. Last week I felt energetic and with vitality...

39. Last week I was concentrated/focused on what I was doing...

40. Last week I felt happy...

4I. Last week I was in a bad mood...

42. Last week I felt worried, anxious or stressed...

43. Last week I felt tired or without vitality...

44. Last week I was bored or without interest in what I was doing...

45. During last week I felt sad...

Second section: adds a set of questions that allows us to know enjoyable or disagreeable situations that the teachers have lived in the last 12 months.

\begin{tabular}{l|l|l|l} 
Mark with an $\mathrm{X}$ the answer that best fits what you have lived in the last 12 & NO
\end{tabular} months:

YES

46. I had to borrow or seek help to pay for food or groceries.

47. I had to borrow or seek help to pay the rent.

48. I had to borrow or seek help to pay the utilities: electricity, water, gas and/or the telephone.

49. I had to borrow or seek help to pay tuition, uniforms and/or school supplies.

50. I had to borrow or seek help to pay for medicine or medical consultation. 


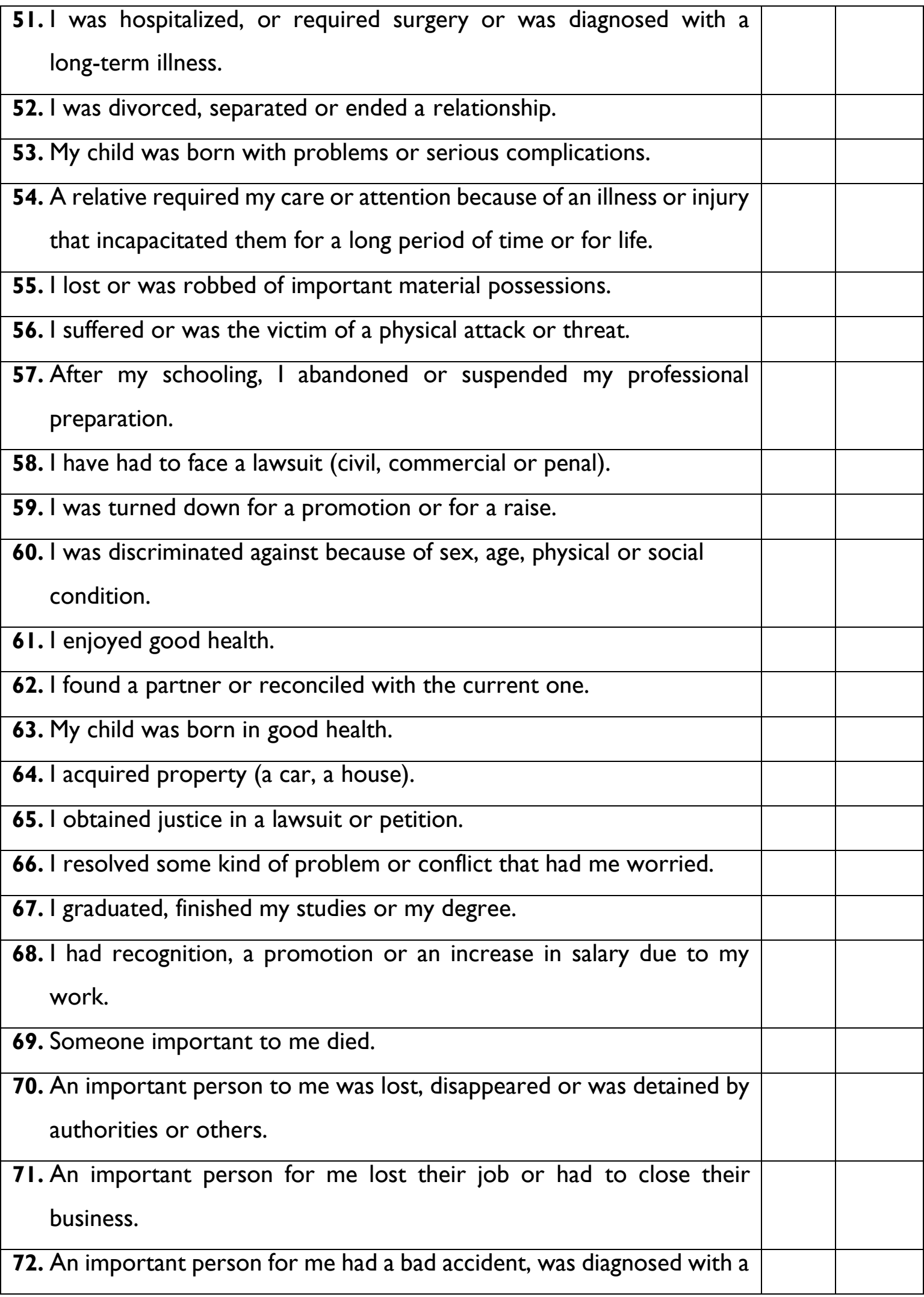


serious or long illness.

73. An important person for me was the victim of a physical or verbal aggression.

74. An important person for me found work, a job or opened a business.

75. An important person for me recuperated from an illness, operation or an accident.

76. An important person for me graduated or finished a degree.

77. An important person for me got into a school of their choice.

78. An important person for me got a promotion or raise in pay at work.

\section{Third section: Personal or work data.}

79. Age: years

80. Sex:

- Female

- Male

8I. Marital status

- Single

- Married

- Free Union, living together

- Divorced

- Widowed

83. Schooling:

- High School

- Technical Career

- Teacher's College

- Bachelor's

- Postgraduate

\section{Number of children:}

- I

- 2

- 3

- 4

- 5 or more

84. Do you speak another language, other than Spanish?

- Yes

- No

85. Which?

86. In which locale do you live? 
87. What is the name of the school or learning center where you work?

88. What is your position where you work?

- Full Professor

- Assistant Professor

- Other

90. How many children under your care in the classroom?

- $1-10$

- $\mid \mathrm{I}-20$

- $21-30$

- $31-40$

- More than $\mathbf{4 0}$

92. What is your monthly income?

- $1,000-2,500$ pesos

- 2,50I - 4,500 pesos

- $4,501-6,500$ pesos

- 6,50I - 10,000 pesos

- $\quad 10,001$ - I5,000 pesos

- $\quad|5,00|$ - 20,000 pesos

- More than 20,000 pesos
89. At what educational level do you teach?

- Beginning

- Preschool

- Grade school

- Junior High School

- Senior High School

- Children's Home

91. How many hours do you spend at work?

- De I - 3

- De 4 - 6

- De 7 - 9

- De $10 \quad 12$

- De 13 - 15

93. How long have you been at your current job?

- Less than 6 months

- $6-12$ months

- I - 2 years

- 3 - 6 years

- 7 - II years

- $12-15$

- More than 15 years

94. In your work experience, 95. What benefits do you 


\begin{tabular}{|c|c|}
\hline $\begin{array}{l}\text { how long have you been } \\
\text { teaching? } \\
\text { Less than } 6 \text { months } \\
6 \text { - I } 2 \text { months } \\
\text { I - } 2 \text { years } \\
3 \text { - } 6 \text { years } \\
7 \text { - II years } \\
\text { I2 - I5 years } \\
\text { More than I5 years } \\
\text { 96. Do you currently } \\
\text { continue your } \\
\text { professional } \\
\text { preparation? } \\
\text { Yes } \\
\text { No }\end{array}$ & $\begin{array}{l}\text { receive where you work? } \\
\text { You can mark more than } \\
\text { one. } \\
\text { - } \quad \text { Fixed salary } \\
\text { - Clear-cut work schedule } \\
\text { - } \quad \text { Days off } \\
\text { - Vacation } \\
\text { - Training } \\
\text { - IMSS Social Security } \\
\text { - Savings Fund } \\
\text { - Other }\end{array}$ \\
\hline
\end{tabular}

